\title{
ON THE EFFECT OF LOW TEMPERATURE ON THE RECOVERY OF OVERSTRAINED IRON AND STEEL.
}

By E. G. CoKer.

HE behavior of iron and steel after overstrain has been the subject of much investigation in recent years at the hands of Ewing ${ }^{1}$ and Muir $^{2}$ and in particular the effect of time and temperature have been very closely studied and it has been shown that iron and steel overstrained in tension when left to itself gradually recovers its elastic properties and in time the recovery is practically complete, while the yield point is raised considerably.

It has also been shown that the recovery is more rapid in wrought iron than in steel, and in either case the recovery is completed in a few minutes by exposing the material to the temperature of boiling water. It appeared, therefore, probable that exposure of an overstrained bar to a low temperature might produce a retarding effect upon the recovery. As the natural facilities afforded by a Canadian winter enable this to be readily tested the author resolved to take advantage of this and to make experiments upon the behavior of iron and steel freely exposed to the atmosphere, but shielded from temperatures above the freezing point.

The behavior of overstrained metal under low temperature is not only interesting from a purely physical point of view, but is of importance in practical applications ; thus bridge structures are liable to stresses which may cause overstrain, and the subsequent behavior of the material under the prolonged low temperatures of northern latitudes is therefore well worthy of study.

The equipment of the McGill Engineering Laboratory was available for the experiments through the kindness of Professor Bovey,

\footnotetext{
1 Ewing, On Measurements of Small Strains in the Testing of Materials and Structures, Proc. R. S., I 895 .

${ }^{2}$ Muir, On the Recovery of Iron from Overstrain, Phil. Trans., 1899.
} 
and included a "Ewing" extensometer similar to others used in the researches mentioned above, and a testing machine of the Buckton type, which afforded a ready means of stressing the bars with ease and accuracy.

\section{Method of Experiment.}

Previous experiments have shown that iron and steel exhibit the same tendency to recover their elasticity with time, whether the stress be tension, compression, shear or bending so that it is a matter of choice as to the way the material shall be stressed. However tension experiments are, as a rule, more easily carried out and this paper is confined to that kind of stress.

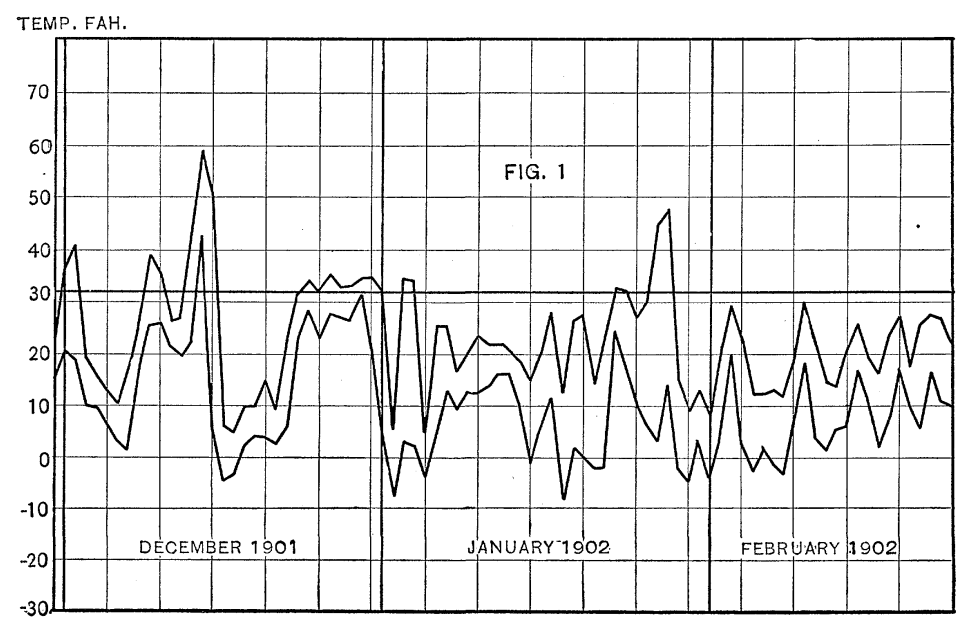

Fig. 1.

The bars under examination were first overstrained in tension and afterwards placed horizontally in the snow with a thin layer above, so that they rapidly acquire the outside temperature. This layer was constantly renewed during a thaw to prevent the temperature rising above $32^{\circ}$ Fahr. The temperature therefore roughly corresponded to that of the atmosphere, but was not allowed to rise above the melting point of snow, except during short intervals when the condition of the specimen was examined under stress in the testing machine. 
In order to show the variations of temperature while the experiments lasted, the maximum and minimum temperatures recorded in the University Observatory, close by, are plotted in Fig. I, from November 30, I90I, the beginning of the experiments, until February 23 , 1902, when they concluded. Soon after this date there was a prolonged thaw and the snow disappeared so rapidly that it was found impossible to keep the bars covered by snow, and the experiments were therefore discontinued. An inspection of the temperature diagram shows that while the work was in progress the temperature was below freezing the greater part of the time and no difficulty was experienced in keeping the bars at or below the meeting point of ice.

The Effect of Low Temperature on Steel Bars.

Two annealed bars were taken, cut from a piece of boiler plate, and these were stressed beyond the yield point in the usual way, and immediately after the condition of each bar was examined by resetting the extensometer and subjecting the material to a cycle of stress starting from no load and rising to an upper limit, in close proximity to the initial yield point and afterwards returning to zero. The stress-strain curves for this second loading showed the wellknown hysteresis effect, and afforded a standard by which to compare the behavior of the bars on subsequent occasions. If a bar overstrained in this way be allowed to rest in a room at ordinary temperature, it will begin to recover at first very rapidly, the rate of recovery diminishing as time goes on, but in general after the lapse of three or four weeks a steel bar regains its primitive elastic condition, provided the permanent extension is not more than two or three per cent.; it has, however, a new yield point much higher than before. As a means of comparison with the two bars under test; some previous results on a bar cut from the same plate may be quoted. This bar had a breadth of 2.07 inches, a thickness of 0.377 inch and a length under test of eight inches. It was stressed until a permanent set of .165 inch was obtained and the following observations were made, the unit of extension throughout being $\frac{1}{10000}$ inch. 


\begin{tabular}{c|c|c}
\hline Load Pounds. & Reading. & Difference. \\
\hline 0 & 200 & 70 \\
4,000 & 270 & 69 \\
8,000 & 339 & 69 \\
12,000 & 408 & 71 \\
16,000 & 479 & 74 \\
20,000 & 553 & \\
23,000 & went off scale. & \\
27,000 & Total Length 8.165 inches. \\
\hline
\end{tabular}

The condition of the bar was now examined by subjecting it to a cyclical loading rising to 24,000 pounds with the following result :

\begin{tabular}{c|c|c}
\hline Load Pounds. & Reading. & Difference. \\
\hline 0 & 200 & 69 \\
4,000 & 269 & 74 \\
8,000 & 343 & 79 \\
12,000 & 422 & 82 \\
16,000 & 504 & 94 \\
20,000 & 598 & 99 \\
24,000 & 697 & 70 \\
20,000 & 627 & 79 \\
16,000 & 548 & 79 \\
12,000 & 469 & 81 \\
8,000 & 388 & 84 \\
4,000 & 304 & 89 \\
0 & 215 & \\
\hline
\end{tabular}

These relations between stress and strain are plotted in Fig. 2, and are marked I. and II. respectively.

The figures representing the actual strains are, however, reduced by subtracting therefrom twenty-five units for each 2,000 pounds of load, thereby shearing back the curves toward the vertical and exhibiting the characteristic differences in a striking manner. This convenient method of plotting, due to Professor Ewing, ${ }^{1}$ is used throughout this paper.

The cyclical loading was repeated at the end of three, seven and twenty-eight days and the observations are recorded on Table I., and plotted on the accompanying Fig. 2.

${ }^{1}$ Muir, On the Recovery of Iron from Overstrain, p. 12. 
No. 2.] RECOVERY OF OVERSTRAINED IRON.

TABle I.

\begin{tabular}{|c|c|c|c|c|c|c|}
\hline \multirow{2}{*}{ Load in Pounds. } & \multicolumn{2}{|c|}{ One Day After. } & \multicolumn{2}{|c|}{ Seven Days After. } & \multicolumn{2}{|c|}{ Twenty-eight Days After. } \\
\hline & Reading. & $\Delta$ & Reading. & $\Delta$ & Reading. & $\Delta$ \\
\hline 0 & 200 & & 200 & & 200 & \\
\hline 4,000 & 269 & $\begin{array}{l}-69 \\
-70\end{array}$ & 268 & -68 & 267 & -67 \\
\hline 8,000 & 339 & $\begin{array}{l}-70 \\
-75\end{array}$ & 338 & -70 & 335 & -68 \\
\hline 12,000 & 414 & $\begin{array}{l}-75 \\
-81\end{array}$ & 409 & -71 & 405 & -70 \\
\hline 16,000 & 495 & $\begin{array}{l}-81 \\
-84\end{array}$ & 484 & -75 & 475 & -70 \\
\hline 20,000 & 579 & $\begin{array}{l}-84 \\
-88\end{array}$ & 561 & -77 & 547 & -72 \\
\hline 24,000 & 667 & $\begin{array}{l}-88 \\
-70\end{array}$ & 647 & -86 & 618 & -71 \\
\hline 20,000 & 597 & $\begin{array}{l}-70 \\
-7 ?\end{array}$ & 579 & -68 & 550 & -68 \\
\hline 16,000 & 524 & $\begin{array}{l}-73 \\
-76\end{array}$ & 509 & -70 & 480 & -70 \\
\hline 12,000 & 448 & $\begin{array}{l}-76 \\
-8 ?\end{array}$ & 435 & -74 & 411 & -69 \\
\hline 8,000 & 366 & $\begin{array}{l}-82 \\
-83\end{array}$ & 358 & -77 & 340 & -71 \\
\hline 4,000 & 283 & $\begin{array}{l}-83 \\
-85\end{array}$ & 281 & -77 & 270 & -70 \\
\hline 0 & 198 & & 2 & -79 & 199 & -71 \\
\hline
\end{tabular}

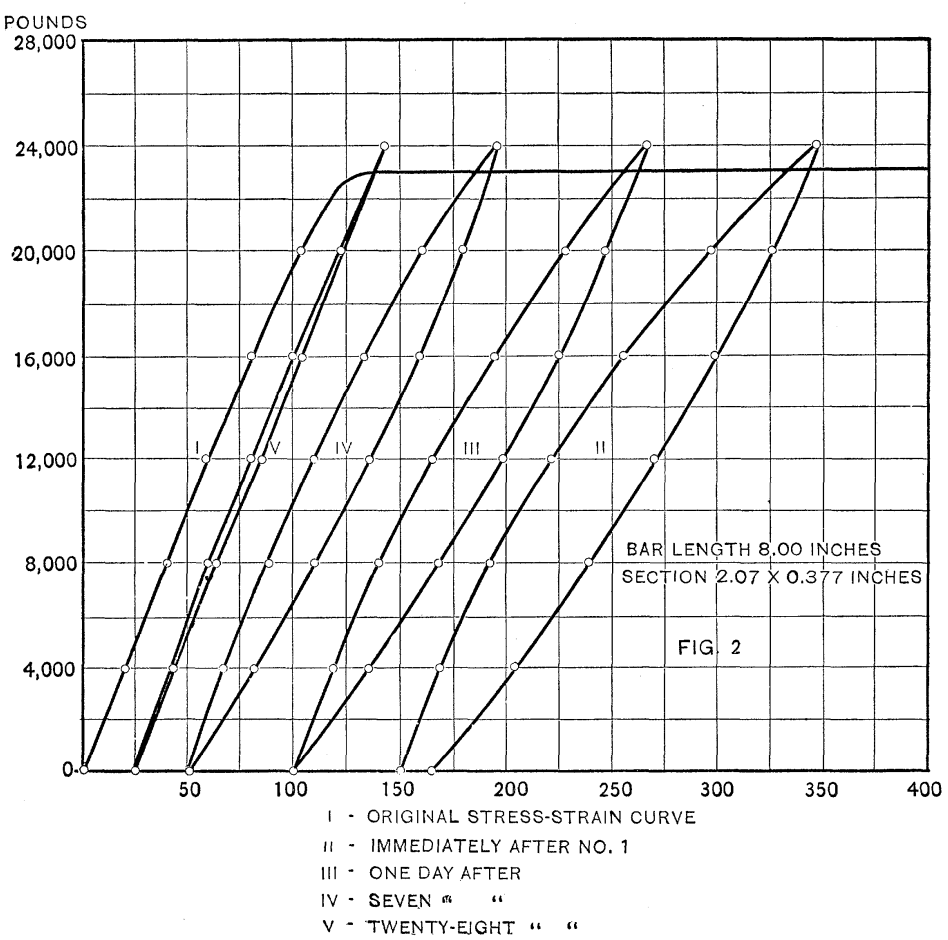

Fig. 2. 
The diagrams show at first a rapid recovery, diminishing with the time, but practically complete in four weeks and are characteristic of the material under the conditions.

We may now compare the behavior of this specimen with a similar specimen kept at the outside temperature. The bar was 2.06 inches in width, .405 inch thick and had a length under test of eight inches, and the unit reading of the extensometer remained the

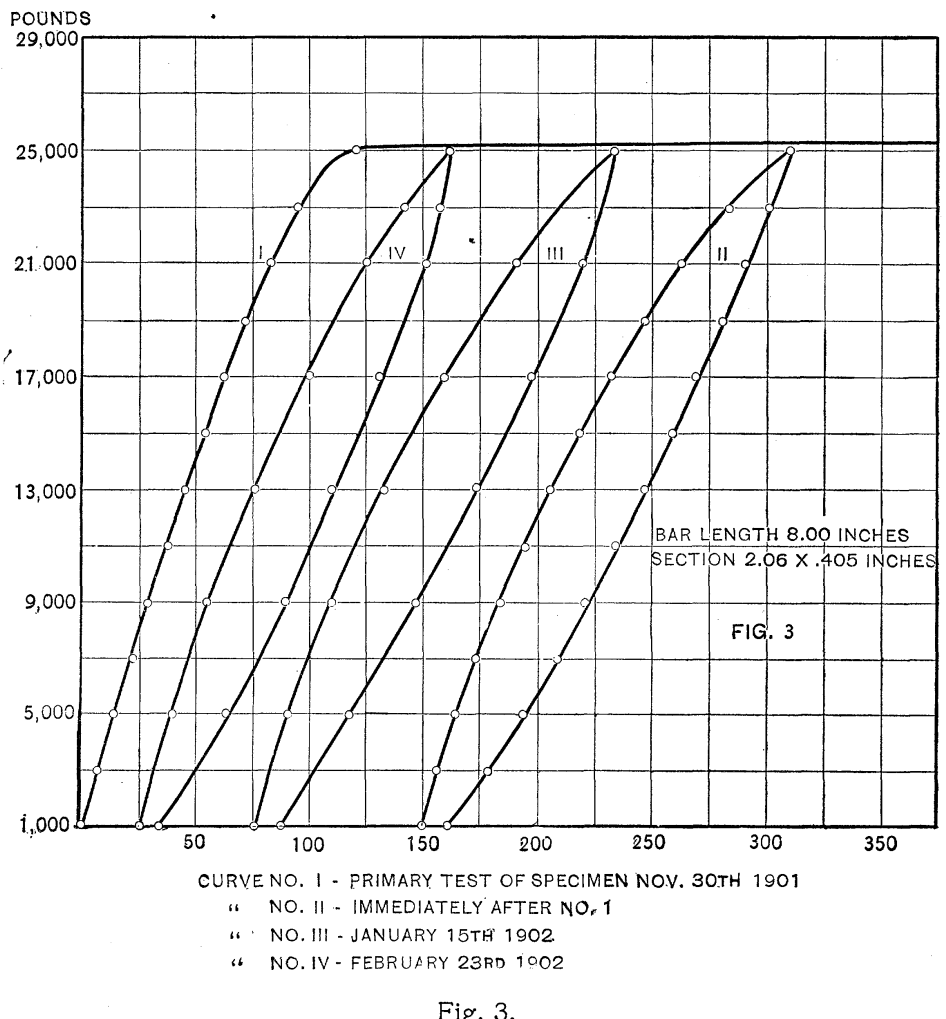

same. The primitive stress strain curve and the hysteresis loop, determined immediately after, are shown in Fig. 3, and the readings are recorded in Table II., from which it will be seen that the agreement is comparatively close; after about six weeks' exposure the stress cycle was repeated and found to be practically unchanged, showing the almost complete arrest of the recovery. 
TABLE II.

1 division $={ }_{50000}$ inch. Bar: Length $=8.00$ inches. Section $=2.06 \times 4.05$ inch.

\begin{tabular}{|c|c|c|c|c|c|c|c|c|}
\hline \multirow{2}{*}{$\begin{array}{l}\text { Load } \\
\text { in Pounds. }\end{array}$} & \multicolumn{2}{|c|}{$\begin{array}{c}\text { November } 30, \\
\text { Igor. }\end{array}$} & \multicolumn{2}{|c|}{$\begin{array}{c}\text { Immediately } \\
\text { After. }\end{array}$} & \multicolumn{2}{|c|}{$\begin{array}{l}\text { January } 15, \\
\text { Ig02. }\end{array}$} & \multicolumn{2}{|c|}{$\begin{array}{c}\text { February 23, } \\
\text { Ig02. }\end{array}$} \\
\hline & Reading. & $\Delta$ & Reading. & $\Delta$ & Reading. & $\Delta$ & Reading. & $\Delta$ \\
\hline 1,000 & 200 & & 200 & & 200 & & 200 & \\
\hline 5,000 & 264 & $\begin{array}{l}-64 \\
-67\end{array}$ & 265 & $\begin{array}{l}-65 \\
-70\end{array}$ & 264 & $\begin{array}{l}-64 \\
-71\end{array}$ & 266 & $\begin{array}{l}-66 \\
-65\end{array}$ \\
\hline 9,000 & 331 & $\begin{array}{l}-67 \\
-65\end{array}$ & 335 & $\begin{array}{l}-70 \\
-72\end{array}$ & 335 & $\begin{array}{l}-71 \\
-73\end{array}$ & 331 & $\begin{array}{l}-63 \\
-71\end{array}$ \\
\hline 13,000 & 396 & $\begin{array}{l}-65 \\
-67\end{array}$ & 407 & $\begin{array}{l}-72 \\
-76\end{array}$ & 408 & $\begin{array}{l}-73 \\
-76\end{array}$ & 402 & $\begin{array}{l}-71 \\
-74\end{array}$ \\
\hline 17,000 & 463 & $\begin{array}{l}-67 \\
-71\end{array}$ & 483 & $\begin{array}{l}-76 \\
-80\end{array}$ & 484 & $\begin{array}{l}-76 \\
-81\end{array}$ & 476 & $\begin{array}{l}-74 \\
-75\end{array}$ \\
\hline 21,000 & 534 & $\begin{array}{l}-71 \\
-86\end{array}$ & 563 & $\begin{array}{l}-80 \\
-100\end{array}$ & 565 & $\begin{array}{l}-81 \\
-91\end{array}$ & 551 & $\begin{array}{l}-75 \\
-9 ?\end{array}$ \\
\hline 25,000 & 620 & & 663 & $\begin{array}{r}-100 \\
-\quad 71\end{array}$ & 656 & $\begin{array}{l}-91 \\
-62\end{array}$ & 643 & $\begin{array}{l}-92 \\
-65\end{array}$ \\
\hline 21,000 & & & 592 & $\begin{array}{l}-71 \\
-71\end{array}$ & 594 & $\begin{array}{l}-62 \\
-72\end{array}$ & 578 & -65 \\
\hline 17,000 & & & 521 & $\begin{array}{l}-71 \\
-73\end{array}$ & 522 & $\begin{array}{l}-72 \\
-74\end{array}$ & 503 & $\begin{array}{l}-75 \\
-69\end{array}$ \\
\hline 13,000 & & & 448 & $\begin{array}{r}-73 \\
-77\end{array}$ & 448 & $\begin{array}{l}-74 \\
-75\end{array}$ & 434 & -69 \\
\hline 9,000 & & & 371 & $\begin{array}{l}-77 \\
-80\end{array}$ & 373 & $\begin{array}{l}-75 \\
-81\end{array}$ & 364 & -70 \\
\hline 5,000 & & & 291 & $\begin{array}{l}-80 \\
-81\end{array}$ & 292 & $\begin{array}{l}-81 \\
-81\end{array}$ & 288 & -76 \\
\hline 1,000 & & & 210 & & 211 & & 209 & \\
\hline
\end{tabular}

The bar was now put back for another five weeks and after the expiration of that time again subjected to test. The observations,

TABLE III.

1 division $={ }_{50 \frac{1}{0} \overline{0} 0}$ inch. Bar $:$ Length $=8.00$ inches. Section $=2.06 \times .374$ inches.

\begin{tabular}{|c|c|c|c|c|c|c|c|c|}
\hline \multirow{3}{*}{$\begin{array}{l}\text { Load } \\
\text { in Pounds. }\end{array}$} & \multicolumn{4}{|c|}{ November 30 , rgor. } & \multirow{2}{*}{\multicolumn{2}{|c|}{ January 15 , 1902. }} & \multirow{2}{*}{\multicolumn{2}{|c|}{ February $23,1902}}$. \\
\hline & \multicolumn{2}{|c|}{$\begin{array}{c}\text { Primary Over- } \\
\text { drain. }\end{array}$} & \multicolumn{2}{|c|}{$\begin{array}{c}\text { Immediately } \\
\text { After. }\end{array}$} & & & & \\
\hline & Reading. & $\Delta$ & Reading. & . $\Delta$ & Reading & $\Delta$ & Reading. & $\Delta$ \\
\hline 1,000 & 200 & & 200 & & 200 & -72 & 200 & -72 \\
\hline 5,000 & 271 & $\begin{array}{l}-71 \\
-71\end{array}$ & 272 & $\begin{array}{l}-72 \\
-77\end{array}$ & 272 & $\begin{array}{l}-72 \\
-76\end{array}$ & 272 & $\begin{array}{l}-72 \\
-75\end{array}$ \\
\hline 9,000 & 342 & $\begin{array}{l}-71 \\
-73\end{array}$ & 349 & $\begin{array}{l}-77 \\
-80\end{array}$ & 348 & $\begin{array}{l}-76 \\
-80\end{array}$ & 347 & $\begin{array}{l}-75 \\
-79\end{array}$ \\
\hline 13,000 & 415 & $\begin{array}{l}-13 \\
-72\end{array}$ & 429 & $\begin{array}{l}-80 \\
-83\end{array}$ & 428 & $\begin{array}{l}-80 \\
-83\end{array}$ & 426 & $\begin{array}{l}-79 \\
-84\end{array}$ \\
\hline 17,000 & 487 & $\begin{array}{l}-72 \\
-73\end{array}$ & 512 & $\begin{array}{l}-83 \\
-86\end{array}$ & 511 & $\begin{array}{l}-83 \\
-89\end{array}$ & 510 & $\begin{array}{l}-84 \\
-85\end{array}$ \\
\hline 21,000 & 560 & $\begin{array}{l}-73 \\
-73\end{array}$ & 598 & $\begin{array}{l}-86 \\
-91\end{array}$ & 600 & $\begin{array}{l}-89 \\
-87\end{array}$ & 595 & $\begin{array}{l}-85 \\
-89\end{array}$ \\
\hline 25,000 & 633 & $\begin{array}{l}-73 \\
-78\end{array}$ & 689 & $\begin{array}{l}-91 \\
-98\end{array}$ & 687 & $\begin{array}{l}-87 \\
-102\end{array}$ & 684 & $\begin{array}{l}-89 \\
-94\end{array}$ \\
\hline 29,000 & 711 & $\begin{array}{l}-78 \\
-68\end{array}$ & 787 & $\begin{array}{l}-98 \\
-53\end{array}$ & 789 & $\begin{array}{r}-102 \\
-53\end{array}$ & 778 & -94 \\
\hline 31,000 & 779 & -68 & 840 & $\begin{array}{l}-53 \\
-36\end{array}$ & 842 & $\begin{array}{l}-53 \\
-37\end{array}$ & 825 & $\begin{array}{l}-47 \\
-34\end{array}$ \\
\hline 29,000 & & & 804 & $\begin{array}{l}-36 \\
-76\end{array}$ & 805 & $\begin{array}{l}-37 \\
-80\end{array}$ & 791 & $\begin{array}{l}-34 \\
-71\end{array}$ \\
\hline 25,000 & & & 728 & $\begin{array}{l}-76 \\
-77\end{array}$ & 725 & $\begin{array}{l}-80 \\
-76\end{array}$ & 720 & -71 \\
\hline 21,000 & & & 601 & -71 & 649 & $\begin{array}{l}-76 \\
-78\end{array}$ & 643 & -77 \\
\hline 17,000 & & & 570 & -81 & 571 & -78 & & -79 \\
\hline 13,000 & & & 485 & -85 & 484 & -87 & $\begin{array}{l}504 \\
482\end{array}$ & -82 \\
\hline 9,000 & & & 399 & -86 & 400 & -84 & 482 & -82 \\
\hline 5,000 & & & 311 & -88 & 314 & -86 & $\begin{array}{l}400 \\
313\end{array}$ & -87 \\
\hline 1,000 & & & 218 & -93 & 220 & -94 & $\begin{array}{l}313 \\
219\end{array}$ & -94 \\
\hline
\end{tabular}


Table II., showed some recovery had taken place, but the bar was still very far from its original condition. Owing to a long continued thaw soon after this, it was found impossible to keep the bar covered by snow and the experiment came to an end. These results are confirmed by the behavior of the companion test piece (Fig. 4) which was subjected to exactly similar treatment. The fig-

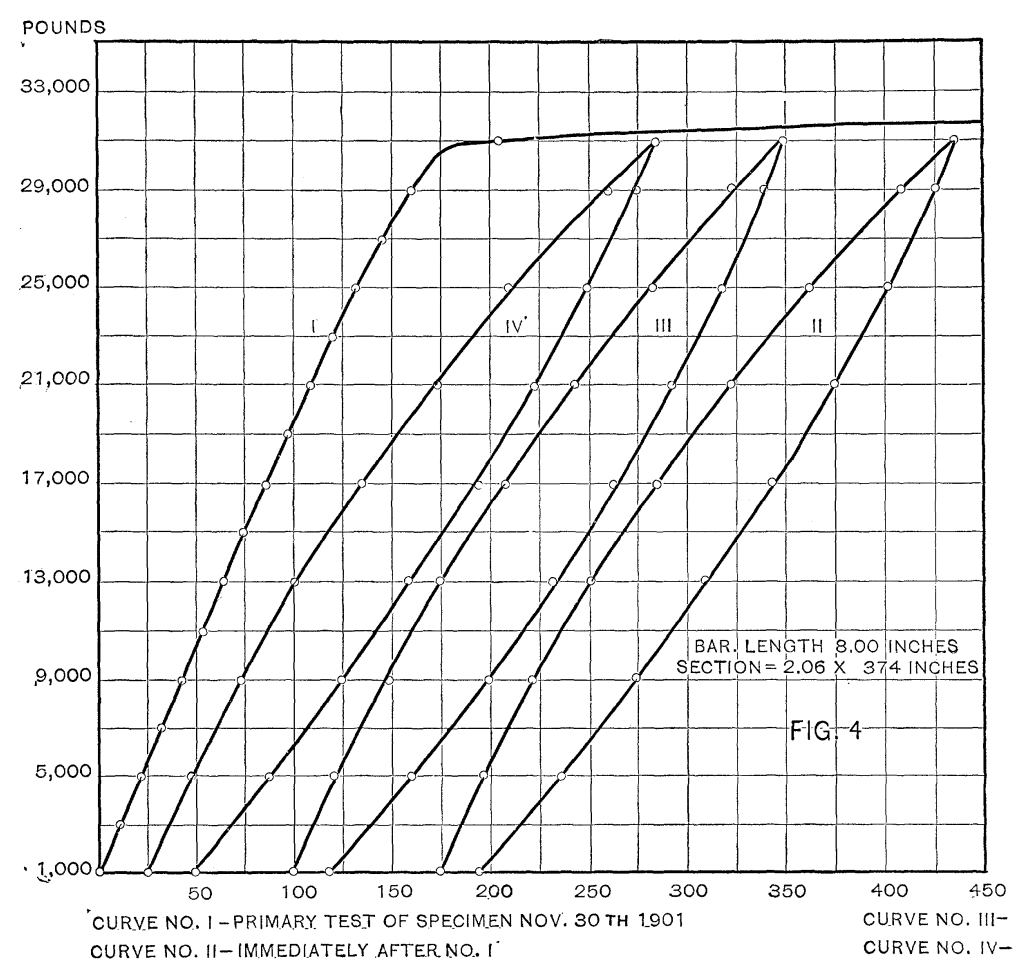

Fig. 4.

ures on Table III. show that there was no recovery during the first six weeks, and at the end of five weeks more some recovery was noticeable. It is, therefore, apparent that a temperature below that of melting ice will cause a very complete arrest of the recovery of an overstrained steel bar, its effect being the exactly opposite to that of temperature at or near the boiling point of water, which latter causes an immediate recovery of the primitive elastic prop. erties. 
The Effect of Moderate Low Temperature on OverSTRAINED WROUGHT-IRON BARS.

It has been pointed out that iron recovers from overstrain at a comparatively rapid rate as compared with steel, and its behavior under low temperature may therefore be somewhat different from steel.

As the conditions of experiment were very nearly the same in both cases, the results afford a comparison of the behavior of iron and steel under corresponding conditions.

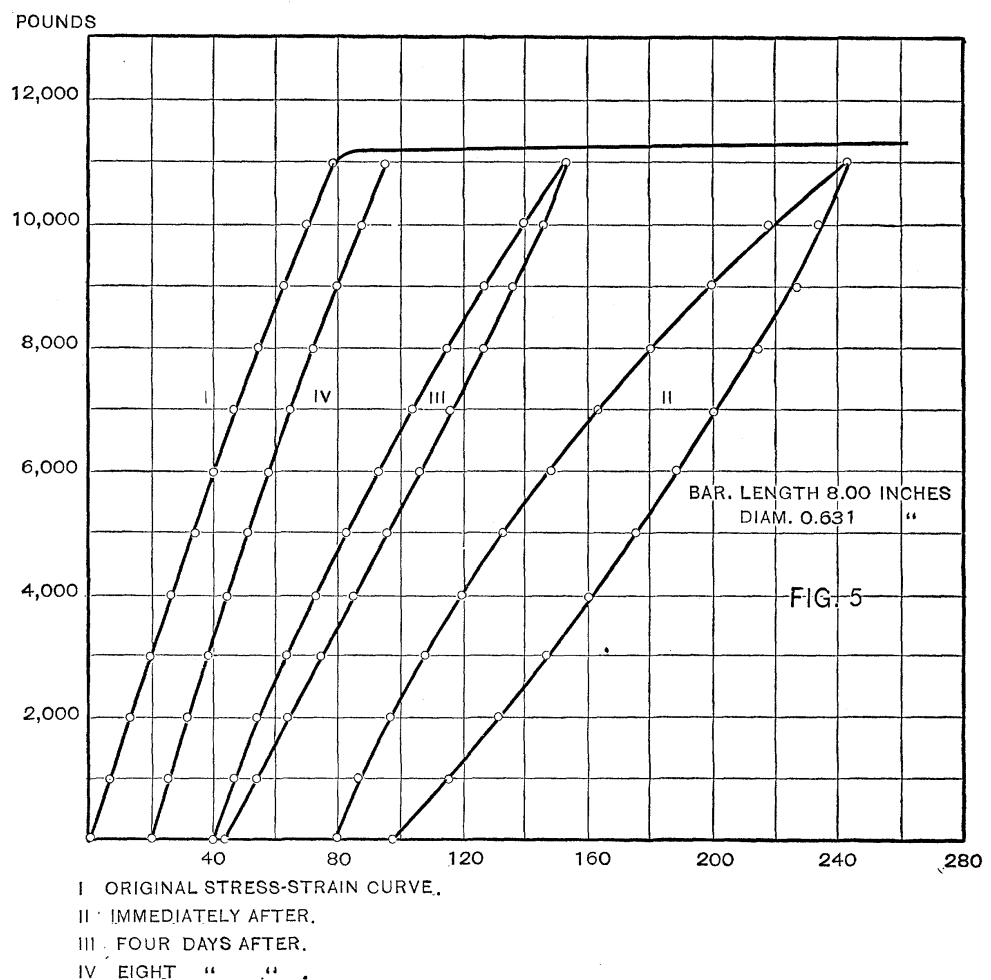

Fig. 5.

Of the three bars chosen, cut from the same rod, one was reserved for a test at the temperature of the laboratory, which never differed much from $65^{\circ}$ Fahr., the other two were overstrained and placed alongside the steel bars in the snow. The rapid recovery of iron in the case of the first specimen is well shown by 
the observations which are given in Table IV., and are represented graphically in Fig. 5.

TABLE IV.

1 division $={ }_{500 \overline{0}}^{1}$ inch. Bar: Length $=8.00$ inches. Diam. $=0.631$ inch.

\begin{tabular}{|c|c|c|c|c|c|c|c|}
\hline \multirow{3}{*}{$\begin{array}{l}\text { Load } \\
\text { in Pounds. }\end{array}$} & \multicolumn{3}{|c|}{ December 20, Igor. } & \multirow{2}{*}{\multicolumn{2}{|c|}{ December 24, rgor. }} & \multirow{2}{*}{\multicolumn{2}{|c|}{ December 28 , Igor. }} \\
\hline & $\begin{array}{l}\text { Primitive } \\
\text { Loading. }\end{array}$ & \multicolumn{2}{|c|}{$\begin{array}{l}\text { Immediately } \\
\text { After. }\end{array}$} & & & & \\
\hline & Reading. $\Delta$ & Reading. & $\Delta$ & Reading. & $\Delta$ & Reading. & $\Delta$ \\
\hline 0 & $200-93$ & 200 & -93 & 200 & -94 & 200 & -92 \\
\hline 2,000 & $\begin{array}{ll}293 & -93 \\
-93\end{array}$ & 293 & $\begin{array}{l}-93 \\
-107\end{array}$ & 294 & $\begin{array}{l}-94 \\
-100\end{array}$ & 292 & $\begin{array}{l}-92 \\
-93\end{array}$ \\
\hline 4,000 & $\begin{array}{ll}386 & -93 \\
-94\end{array}$ & 400 & -108 & 394 & -100 & 385 & $\begin{array}{l}-92 \\
-92\end{array}$ \\
\hline 6,000 & $\begin{array}{ll}480 & -94 \\
-94\end{array}$ & 508 & -112 & 494 & -100 & 477 & $\begin{array}{r}72 \\
-94\end{array}$ \\
\hline 8,000 & $\begin{array}{ll}574 & -94 \\
-92\end{array}$ & 620 & -117 & 595 & $\begin{array}{r}101 \\
-104\end{array}$ & 571 & -98 \\
\hline 10,000 & $\begin{array}{ll}666 & -92 \\
-52\end{array}$ & 737 & $\begin{array}{l}-111 \\
-65\end{array}$ & 699 & $\begin{array}{l}-104 \\
-55\end{array}$ & 669 & -50 \\
\hline 11,000 & $718^{-52}$ & 802 & $\begin{array}{l}-03 \\
-49\end{array}$ & 754 & $\begin{array}{l}-30 \\
-49\end{array}$ & 719 & -48 \\
\hline 10,000 & $12,500 \mathrm{lbs} .=8.3^{\prime \prime}$ & 753 & $\begin{array}{l}-49 \\
-99\end{array}$ & 705 & $\begin{array}{l}-49 \\
-98\end{array}$ & 671 & $\begin{array}{l}-40 \\
-98\end{array}$ \\
\hline 8,000 & & 654 & $\begin{array}{l}-99 \\
-106\end{array}$ & 607 & $\begin{array}{r}50 \\
-101\end{array}$ & 573 & $\begin{array}{r}-90 \\
-94\end{array}$ \\
\hline 6,000 & & 548 & $\begin{array}{l}-100 \\
-108\end{array}$ & 506 & -100 & 478 & -94 \\
\hline $.4,000$ & & 440 & $\begin{array}{l}-108 \\
-108\end{array}$ & 406 & $\begin{array}{r}100 \\
-102\end{array}$ & 385 & $\begin{array}{r}94 \\
-94\end{array}$ \\
\hline 2,000 & & 332 & -114 & 304 & -101 & 291 & $\begin{array}{r}-94 \\
-92\end{array}$ \\
\hline 0 & & 218 & & 203 & & 199 & \\
\hline
\end{tabular}

The recovery in the case of this bar is nearly four times as rapid as the corresponding steel bar. It should, however, be noted that through the accidental circumstance of the permanent stretch 0.3 inch being more than was intended, the rate of recovery is not strictly comparable, but it shows sufficiently well the difference in the behavior of the two.

- As the dimensions and loads were so different from the previous cases it was found convenient in plotting the observations for the wrought-iron specimens to shear back the curves in the ratio of forty units for each thousand pounds of load.

The recovery of a similar bar when subjected to moderate low temperature is, as might be expected, quite different from the former case, but it does not resemble steel in its behavior. This is illustrated by the case of a wrought-iron specimen, which immediately after overstrain on December 7 was placed in the snow and allowed to remain there until January i 5 following. The observations, Table V., showed that a decided recovery had taken place during the interval. The bar was put back and again tested on February 23, and showed only a slight recovery. 
TABLE V.

Wrought-iron bar $C$. Mean diameter $=0.621 \mathrm{inch.} \mathrm{Length}=8.00$ inches. 1 division $={ }_{50000}^{1}{ }_{0} \mathrm{inch}$.

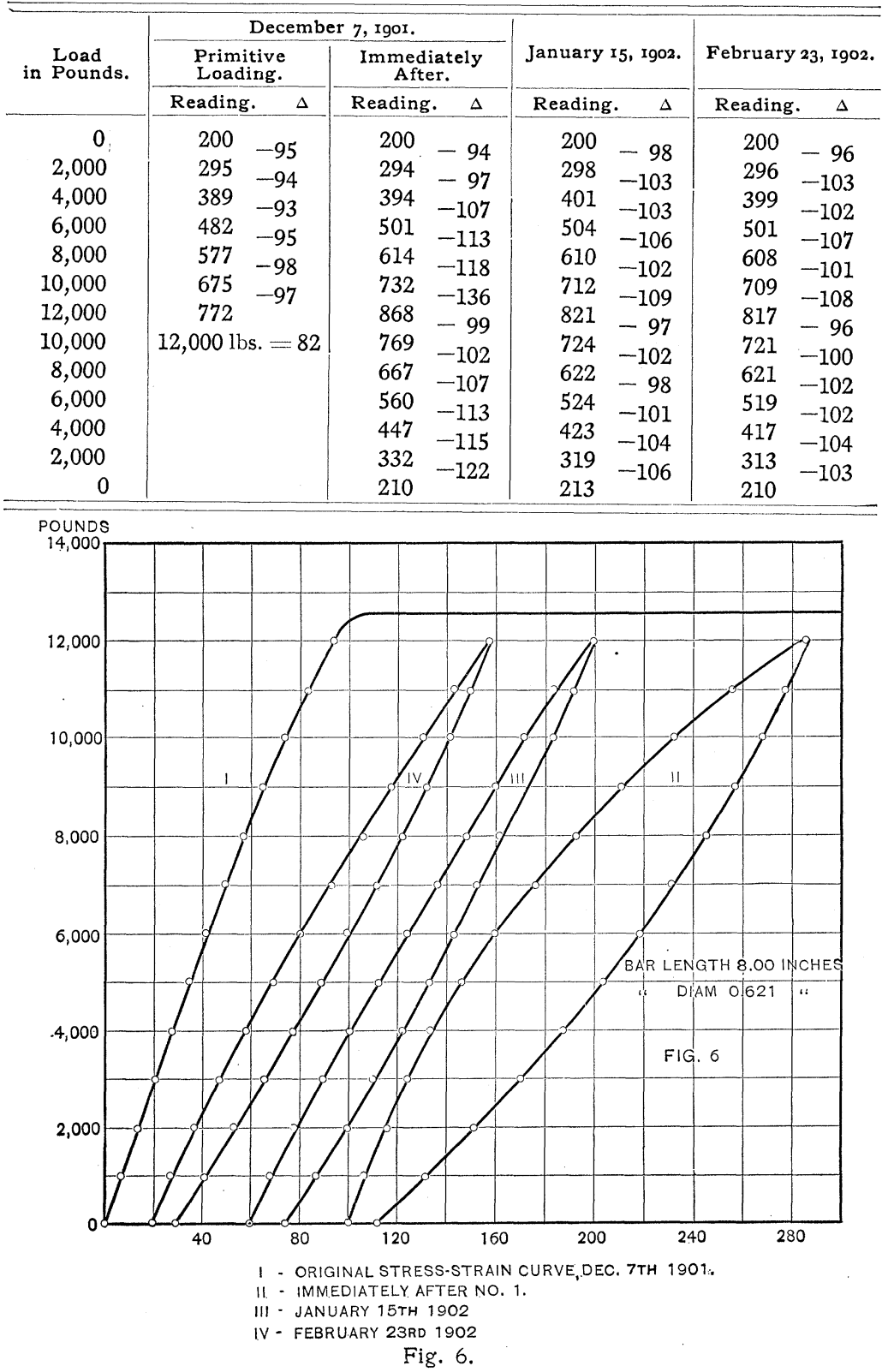


These observations are plotted in Fig. 6 in which II. is the hysteresis loop immediately after overstrain, which, as before, serves as a standard of comparison of the behavior of the bar.

The recovery at the end of the first period is apparent by the large diminution in the hystereses between stress and strain, but there was practically no further recovery after a second interval of about the same duration as is shown by the almost precisely equal loop marked IV.

TABLE VI.

Wrought-iron bar D. Mean diameter $=0.637$. Length $=8.00$ inches. 1 division $=\frac{5}{50} \frac{1}{000}$ inch.

\begin{tabular}{|c|c|c|c|c|c|c|c|c|}
\hline \multirow{2}{*}{$\begin{array}{l}\text { Load } \\
\text { in Pounds. }\end{array}$} & \multicolumn{2}{|c|}{$\begin{array}{l}\text { Primitive } \\
\text { Loading. }\end{array}$} & \multicolumn{2}{|c|}{$\begin{array}{c}\text { Immediately } \\
\text { After. }\end{array}$} & \multicolumn{2}{|c|}{$\underset{\text { IgO2. }}{\text { January } \mathrm{I}_{5},}$} & \multicolumn{2}{|c|}{$\begin{array}{c}\text { February } 23, \\
\text { Ig02. }\end{array}$} \\
\hline & Reading. & $\Delta$ & Reading. & $\Delta$ & Reading. & $\Delta$ & Reading. & $\Delta$ \\
\hline 0 & 200 & & 200 & & 200 & & 200 & \\
\hline 2,000 & 293 & $\begin{array}{l}-93 \\
-01\end{array}$ & 298 & $\begin{array}{r}-98 \\
-90\end{array}$ & 293 & $\begin{array}{l}-93 \\
-99\end{array}$ & 294 & \\
\hline 4,000 & 384 & $\begin{array}{l}-91 \\
-02\end{array}$ & 397 & $\begin{array}{l}-99 \\
-107\end{array}$ & 392 & $\begin{array}{l}-99 \\
-\quad 97\end{array}$ & 394 & -100 \\
\hline 6,000 & 477 & $\begin{array}{l}-93 \\
-91\end{array}$ & 504 & $\begin{array}{l}-107 \\
-110\end{array}$ & 489 & $\begin{array}{l}-97 \\
-102\end{array}$ & 495 & $\begin{array}{l}-101 \\
-102\end{array}$ \\
\hline 8,000 & 568 & $\begin{array}{l}-91 \\
-91\end{array}$ & 614 & -110 & 591 & $\begin{array}{l}-102 \\
-102\end{array}$ & 597 & $\begin{array}{l}-102 \\
-103\end{array}$ \\
\hline 10,000 & 659 & $\begin{array}{l}-91 \\
-90\end{array}$ & 733 & $\begin{array}{l}-119 \\
-137\end{array}$ & 693 & $\begin{array}{l}-102 \\
-118\end{array}$ & 700 & -103 \\
\hline 12,000 & 749 & -90 & 870 & 37 & 811 & -118 & 803 & $\begin{array}{r}-103 \\
-\quad 03\end{array}$ \\
\hline 10,000 & $12,500 \mathrm{lbs}$ & $=8$ & 770 & -100 & 703 & $\begin{array}{l}-108 \\
-07\end{array}$ & 710 & -93 \\
\hline 8,000 & & & 669 & -101 & 606 & -97 & 611 & - 99 \\
\hline 6,000 & & & 501 & -108 & 509 & -97 & 513 & -98 \\
\hline 4,000 & & & 449 & -112 & 408 & $\begin{array}{l}-101 \\
-102\end{array}$ & 412 & -101 \\
\hline 2,000 & & & 334 & & 306 & -102 & 311 & -101 \\
\hline 0 & & & 214 & & 202 & & 206 & 105 \\
\hline
\end{tabular}

The second bar under precisely similar conditions, except that the permanent stretch was greater, gave similar results, as is shown by Table VI., in which the diminution of the overstrain during the first period is large but is practically reduced to nothing in the second interval.

This anomalous behavior of wrought iron after overstrain may be explained if we consider that beyond a certain point the action of the low temperature is insufficient to maintain the condition of overstrain, which therefore gradually diminishes until a point is reached at which the tendency to recover is balanced by the opposing action of temperature.

On this view the tendency to recover from overstrain in the case of the steel is entirely balanced by the opposing effect of the temperature and its recovery is in consequence entirely arrested. 